\title{
Application of biofertilizer directly on 'Terra Maranhão' platain bunch for productivity gain
}

\author{
Sávio da Silva Berilli1, Mateus Francisco Pazinato ${ }^{2}$, Carlos Humberto Desiderio Pirovani ${ }^{3}$, \\ Samuel Paulo Torrezani ${ }^{4}$, Lucas Louzada Pereira ${ }^{5}$, Ana Paula Cândido Gabriel Berillí ${ }^{6}$
}

\begin{abstract}
Advances in production systems always aim at finding alternatives to improve crop productivity. One of the recent practices adopted in commercial banana and plantain plantations refers to the application of liquid fertilizers in bunches in order to increase productivity. This research aimed at verifying whether the use of biofertilizers based on pure vinasse or associated with other chemical fertilizers would provide morphophysiological changes in fruits or increase the productivity of 'Terra Maranhão' plantain cultivars. In order to carry out this project, a randomized block design with 6 treatments and 3 replicates was set up in a commercial crop and the postharvest production and quality characteristics of 'Terra Maranhão' plantain fruits were evaluated. The results showed that the morphophysiological characteristics of freshly harvested fruits that impact productivity such as the fruit weight and bunch weight were affected by treatments, as the postharvest characteristics of ripe fruits were little affected by the application of fertilizers in bunches, except for the SST content. It could be concluded that the crop yield increased significantly by $17 \%$ when using mixture of vinasse, potassium chloride and urea; however, this treatment caused significant reduction of $1.3^{\circ}$ Brix compared to control.

Index terms: Banana; Plant Nutrition; Vinasse; Residue; Bunch spraying.

\section{Aplicação de biofertilizante dirigido ao cacho do plátano Terra Maranhão para ganho de produtividade}

Corresponding author: savio.berilli@ifes.edu.br

Received: April 22, 2021 Accepted: October 13, 2021

Copyright: All the contents of this journal, except where otherwise noted, is licensed under a Creative Commons Attribution License.

\section{$(\mathrm{cc}) \mathbf{E Y}$}

Resumo- Os avanços nos sistemas de produção buscam sempre alternativas para a melhoraria da produtividade. Uma das práticas recentes adotadas em plantios comerciais de bananas e plátanos referem-se à aplicação de fertilizantes líquidos em cachos, visando ao aumento da produtividade. $\mathrm{O}$ objetivo deste trabalho foi verificar se o uso de biofertilizantes à base de vinhaça pura ou associada a outros adubos químicos poderia proporcionar alterações morfofisiológicas nos frutos ou aumento de produtividade no plátano cv Terra Maranhão. Para a execução deste projeto, foi montado, em uma lavoura comercial, um delineamento em blocos casualizados, com 6 tratamentos e 3 repetições, tendo sido avaliada a características de produção e qualidade dos frutos na póscolheita do plátano cultivar (cv) Terra Maranhão. Como resultado, pôde-se observar que as características morfofisiológicas de frutos recém-colhidos, que impactam a produtividade, como peso dos frutos e dos cachos, foram afetados pelos tratamentos, enquanto características da póscolheita dos frutos maduros foram pouco afetadas pela aplicação de fertilizantes nos cachos, com exceção do conteúdo de SST. Conclui-se, portanto, com este experimento, que a produtividade da cultura aumentou significativamente em $17 \%$ quando utilizado uma mistura de vinhaça, cloreto de potássio e ureia, entretanto, esse mesmo tratamento provocou uma redução significativa de 1,3 ${ }^{\circ}$ Brix em relação a testemunha.

Termos para indexação: Banana; Nutrição de plantas; Vinhaça; Vinhoto; Resíduo; Pulverização no cacho.

${ }^{1}$ Ph.D. in Plant Production, Laboratory of Phytotechnics. Federal Institute of Espírito Santo, Campus of Alegre, Alegre-ES, Brazil. Email: savio. berilli@ifes.edu.br(ORCID 0000-0003-0554-8756)

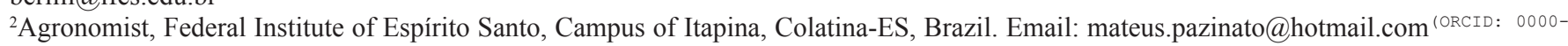
0001-8413-4038)

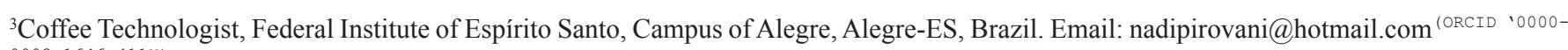
0003-1646-411X)

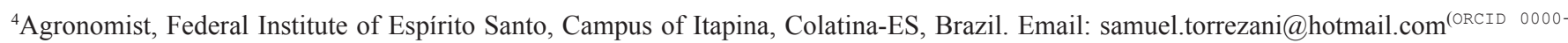
0002-0615-9157)

${ }^{5}$ Ph.D. in Production Engineering, Federal Institute of Espírito Santo, Campus of Venda Nova do Imigrante, Venda Nova do Imigrante-ES,

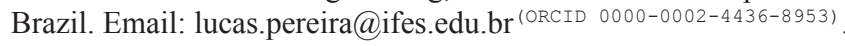

${ }^{6} \mathrm{Ph} . \mathrm{D}$. in Genetics and Crop Breeding, Federal Institute of Espírito Santo, Campus of Alegre, Alegre-ES, Brazil, ana.berilli@ifes.edu.br ${ }^{(\mathrm{ORCID}}$ 0000-0002-9229-4653) 


\section{Introduction}

Plantains (Musa acuminata x Musa balbisiana hybrid) are cultivated and appreciated throughout Central and Latin America, and can be consumed in the fresh form or as flour in human nutrition (REIS et al., 2019). In Brazil, the most appreciated and planted plantain cultivar is 'Terra Maranhão', which has long cycle compared to other cultivars and requires large amounts of nutrients in all its phases, especially in the phase of bunch weight gain. It is also known that the nutrient that this crop needs in greater amount is potassium, which directly favors bunch weight gain. In addition, potassium deficiency in weak soils or insufficient nutrition produces small bunches, with small and light-weight fruits (SILVA et al, 2011), which are undesirable characteristics for marketing.

Mineral nutrition in commercial banana plantations is an essential part for the success of the activity, with fertilization directed to the soil being the main and only way of fertilization in most cases (AULAR; NATALE, et. al., 2013), with fertilizer sources based on conventional chemical fertilizers and/or alternative fertilizers, such as biofertilizers. With the advance in banana cultivation practices, studies on the use of biofertilizers have been developed with different purposes, including mineral nutrition and soil conditioning (RIVERA-CRUZ et al., 2008; GURAV; JADHAV, 2013; SANTOS et al.., 2014; SENTHILKUMAR et al., 2014; BERILLI et al., 2020; BERILLI et al., 2021), even as a measure against banana crop diseases (FU et al., 2017; HUANG et al., 2019; WIDYANTORO; HADIWIYONO, 2020).

Studies carried out with 'Nanicão' banana cultivar regarding the soil application of biofertilizers (combined organic and inorganic materials), have revealed that there were no significant differences in fruit quality as a function of applied treatments (SANTOS et al., 2014). Other authors, when studying the influence of biofertilizers based on decomposed chicken feather, also applied to the soil, observed improvements in soil quality and significant increases in the amount of antioxidants present in fruits, such as total phenolic compounds and flavonoids (GURAV; JADHAV., 2013). However, none of these studies inferred on productivity gains regarding the use of biofertilizers.

Vinasse is a residue derived from the production of alcohol and cachaça, with high potassium concentration, among other elements, being well known in the agricultural environment for being widely used in sugarcane plantations (COSTA et al., 2021); however, its high potassium levels raise the possibility of using this biofertilizer combined with other elements in other agricultural crops, such as plantains, due to the high demand for this element in the crop (SILVA et al, 2011).
In addition to soil fertilization, a new technique among plantain producers in the state of Espírito Santo has been adopted in commercial crops, which is the application of liquid fertilizers directed to fruit bunches after flowering in order to increase productivity; however, there are no reports in literature showing the effectiveness of this technique. In this sense, in order to use vinasse as the basis of a potential liquid biofertilizer, this work aims to verify whether pure vinasse or associated with other chemical fertilizers, applied directly to fruits during development, provides positive morphophysiological changes in the fruit and/or increases the productivity of 'Terra Maranhão' plantain cultivar.

\section{Material and methods}

The experiment was installed and conducted in a commercial plantation in a rural property located near the city of Colatina - ES, on the banks of the Doce River, with geographic coordinates; $19^{\circ} 31^{\prime} 19.64$ ' S, 40 42' 43.23" $\mathrm{W}$ and 56 meters above sea level.

The planting was originated from conventional seedlings produced in the farm, being irrigated by microsprinkler and all cultural treatments were carried out by the producing farm in accordance with cultivation recommendation proposed by Alves (1999). The plantain variety used in this experiment derives from the cross between Musa acuminata and Musa balbisiana, called 'Terra Maranhão' (BRS PL01) plantain, with high size and high productivity, recorded by Ferreira and Santos-Serejo (2018), under registration number with the Ministry of Agriculture of 38402 .

Due to the high plant size and bunch weight, plants were supported with eucalyptus props, and planting was annually renewed, not allowing the development of rhizome sprouts. Planting was performed in a $2 \times 2$ meters spacing between plants (double rows) and 4 meters between rows, corresponding to 1666 plants per hectare.

The intervention in the production area took place only at the time of the application of treatments, and for this purpose, a randomized block design with 6 treatments and 3 replicates was set up, with each experimental plot having 5 plants in the planting row, being the three central plants considered useful, totaling 54 useful plants and total of 90 plants in the experiment. Treatments are described in Table 1. 
Table 1. Description of treatments using sugarcane vinasse derived from the production of cachaça, commercial products and chemical fertilizers

\begin{tabular}{ll}
\hline \multicolumn{1}{c}{ Treatments: } & \multicolumn{1}{c}{ Description: } \\
\hline T-0 (Control) & Solution with $100 \%$ water \\
T-C $($ Commercial product $*)$ & Solution with $8 \mathrm{ml}$ of Alga $+\circledR$ added to $30 \mathrm{ml}$ of Frut Plus ${ }^{\circledR}$ diluted in 10 \\
T-V (Pure Vinasse $* *)$ & liters of water \\
\hline
\end{tabular}

T-VC (Vinasse + Commercial product) Solution with $8 \mathrm{ml}$ of Alga $+\circledR$ added to $30 \mathrm{ml}$ of Frut Plus ${ }^{\circledR}$ diluted in vinasse

$\mathrm{T}-\mathrm{VK}\left(\right.$ Vinasse $\left.+\mathrm{KCl}^{* * *}\right) \quad$ Solution with vinasse + complement with $369 \mathrm{~g}$ of $\mathrm{KCl}$

T-VKN (Vinasse $+\mathrm{KCl}+$ Urea***) $^{*} \quad$ Solution with vinasse + complement with $369 \mathrm{~g}$ of KCl and $30.15 \mathrm{~g}$ of Urea

* Commercial product commonly used in the farm where the experiment was implemented;

** Vinasse used as a diluting solution in a volume of 10 liters;

** $\mathrm{KCl}$ and Urea used in the amounts necessary to complement the equivalent values of potassium and nitrogen observed in commercial products, taking into account the amount of these elements in the vinasse.

The vinasse used in this experiment derived from the production of cachaça in property located in the municipality of Santa Rita do Ituêto - MG. Some nutritional characteristics of both vinasse and commercial products used in this experiment are described in Table 2. Based on the nutritional values of vinasse through chemical analysis presented in Table 2, nutritional balance was performed in treatments with vinasse $+\mathrm{K}(\mathrm{T}-\mathrm{VK})$ and vinasse $+\mathrm{K}+\mathrm{N}(\mathrm{T}-\mathrm{VKN})$, so that treatments using vinasse were quantitatively equivalent to potassium (using $\mathrm{KCl}$ ) and nitrogen (using urea) levels present in the commercial product, providing equivalent concentration of $3.49 \mathrm{~g} . \mathrm{dm}^{-3}$ of $\mathrm{N}$ and $38.16 \mathrm{~g} . \mathrm{dm}^{-3}$ of $\mathrm{K}_{2} \mathrm{O}$ between T-C and T-VKN treatments.

Table 2. Composition of inputs and vinasse derived from the production of cachaça used in treatments

\begin{tabular}{|c|c|c|c|c|}
\hline Inputs/Vinasse & $\mathbf{P}_{2} \mathrm{O}_{5} \quad \mathrm{~K}_{2} \mathrm{O}$ & $\mathbf{N}$ & Mg & $\mathbf{Z n}$ \\
\hline $\operatorname{Alga}^{+}{ }^{\circledR} *$ & 390 & 115 & 11.5 & 5.75 \\
\hline Vinasse & $0.05 \quad 1.26$ & 0.48 & 0.13 & 0.004 \\
\hline
\end{tabular}

*Characteristics of the mixture of both products used in treatments.

Treatments were weekly applied with a motorized back spray, reaching only the bunch and lasted, from the period of complete bunch opening, 52 days, which corresponded to 7 weeks of treatment applications, always on the same day of the week on which the first application was applied, regardless of weather conditions, until harvest. To avoid possible burning of fruits, all applications were carried out in the morning from 07:00 am to 10:00 am. Due to the large plant size, a long spear was used for application in bunches, minimizing drift of the applied spray. The nozzle used was JD 12 jacto ${ }^{\circledR}$ type, $1.2 \mathrm{~mm}$ disc, black, empty cone jet shape, small drops with angle of 80 degrees at 60 psi.

After the first signs of ripening of bunches in the experiment, spray applications ceased. Bunches were harvested according to the physiological ripening point identified by the color change. On harvest days, bunch weight (PC), weight of the fallen bunch (PMP), weight of the third bunch from apex to base (PTP) and rachis weight (PX) measurements were performed. Fruit length (CF) and fruit diameter (DF) were also evaluated, and for this, the fifth fruit from left to right from the third bunch from apex to base on the external side was used as a standard for all treatments, measuring the diameter of the fruit between its lateral corners, and the length on the concave side. The measured fruit was marked with a loose ribbon loop on the stem to facilitate visualization and follow-up during subsequent measurements.

After harvesting and initial evaluations, bunches were placed in a masonry room without the presence of light and bananas ripened naturally to the point of consumption (100\% yellow), when they were submitted to the following evaluations: fruit weight (PF - fifth fruit from left to right of the third bunch from apex to base), Total Soluble Solids (SST) measured in degrees ${ }^{\circ}$ Brix (GB), pulp weight (PP), peel weight (PC), and yield (PRD), taking into account planting density and bunch weight. Postharvest evaluations were carried out at the Food Laboratory of the Federal Institute of Espírito Santo - IFES, Campus of Itapina.

The statistical treatment of data went through analysis of variance of the means of treatments and, when significant, Tukey's average tests were carried out at maximum level of $5 \%$ of error probability. The methodology presented in this work is protected and registered with the National Institute of Intellectual Property (INPI) under number BR1020200090330. 


\section{Results and discussion}

By analyzing results, it was observed that the morphological characteristics evaluated did not present significant differences in relation to treatments applied, but for some gravimetric characteristics, fruit quality and production, significant differences were observed so that 6 of the 13 characteristics evaluated in this experiment were significantly influenced by the application of biofertilizers directed to 'Terra Maranhão' banana bunches.

Characteristics such as fruit length and diameter and the relationship between these two parameters were not significant regarding the application of biofertilizers directed to the bunch (Table 3). Unlike results obtained in this experiment, Santos et al. (2014) studied four mixtures of biofertilizers based on rock flour, wood ash, sugar, manure and milk whey and observed the influence of these treatments on the length and diameter of 'Nanicão' fruits, even if $\mathrm{N}$ and $\mathrm{K}$ concentrations in this biofertilizer were smaller than those used in this experiment (in the order of 2.6 and 51 times smaller in relation to $\mathrm{N}$ and $\mathrm{K}_{2} \mathrm{O}$, respectively).

Tables 3. Effect of seven applications, during the production phase, with different products and mixtures of biofertilizer and chemical fertilizers in 'Terra Maranhão' banana bunches on variables Mean length (CF), diameter (DF) and Length/ Diameter ratio (CF/DF) of fruits at 52 days after the bunch establishment in freshly harvested green fruits

\begin{tabular}{cccc}
\hline Treatment & $\begin{array}{c}\text { Length } \\
\mathbf{c m}\end{array}$ & $\begin{array}{c}\text { Diameter } \\
\mathbf{m m}\end{array}$ & $\begin{array}{c}\mathbf{C F} / \mathbf{D F} \\
\text { ratio }\end{array}$ \\
\hline T-0 & $19.8 \mathrm{a}$ & $35.2 \mathrm{a}$ & $0.56 \mathrm{a}$ \\
$\mathrm{T}-\mathrm{C}$ & $19.7 \mathrm{a}$ & $33.4 \mathrm{a}$ & $0.59 \mathrm{a}$ \\
$\mathrm{T}-\mathrm{V}$ & $20.0 \mathrm{a}$ & $35.2 \mathrm{a}$ & $0.58 \mathrm{a}$ \\
$\mathrm{T}-\mathrm{VC}$ & $20.2 \mathrm{a}$ & $34.7 \mathrm{a}$ & $0.59 \mathrm{a}$ \\
$\mathrm{T}-\mathrm{VK}$ & $19.7 \mathrm{a}$ & $34.4 \mathrm{a}$ & $0.58 \mathrm{a}$ \\
T-VKN & $20.2 \mathrm{a}$ & $35.1 \mathrm{a}$ & $0.58 \mathrm{a}$ \\
\hline Average & 19.2 & 34.7 & 0.58 \\
\hline $\mathrm{CV}(\%)^{*}$ & 8.5 & 8.7 & 11.14 \\
\hline
\end{tabular}

Means followed by letters distinct from each other in the column differ statistically from each other by the Tukey test at $5 \%$ level. * Coefficient of variation.

The experiment carried out by Santos et. al. (2014), previously mentioned, applied biofertilizers directly to the soil, different from the methodology used in this experiment, which promoted direct application to the bunch. The different sources and forms of application of biofertilizers certainly account for the different results observed between these two experiments for characteristics such as fruit length and diameter, because the absorption of elements via fruit peel is subtler and less expressive when compared to the absorption of elements via the root system by mass flow.
Differently from the morphological characteristics presented in Table 3, it was possible to detect significant differences in characteristics that affect crop productivity, such as bunch weight and average bunch weight, which culminated in productivity gain (Table 4 ). For these three characteristics, the treatment that received the mixture of vinasse, urea and potassium chloride (T-VKN) showed the greatest gains, reaching difference of $13.1 \mathrm{t} / \mathrm{ha}(17 \%)$ when compared to control ( $\mathrm{T}-0)$.

Table 4. Effect of seven applications, during the production phase, with different products and mixtures of biofertilizer and chemical fertilizers in 'Terra Maranhão' banana bunches on variables Bunch weight (PC), Weight of the fallen bunch (PMP), Rachis weight (PX), mean number of bunches (NP) and yield per hectare (PRD) of fruits at 52 days after bunch establishment, in freshly harvested green fruits

\begin{tabular}{|c|c|c|c|c|c|}
\hline Treatment & PC & $\begin{array}{l}\text { PMP } \\
--k g \\
\end{array}$ & PX & $\begin{array}{c}\text { NP } \\
\text { Unit }\end{array}$ & $\begin{array}{l}\text { PRD } \\
\text { t.ha }^{-1}\end{array}$ \\
\hline $\mathrm{T}-0$ & $46.4 \mathrm{~b}$ & $43.6 \mathrm{bc}$ & $2.9 \mathrm{a}$ & $9.6 \mathrm{a}$ & $77.3 \mathrm{~b}$ \\
\hline $\mathrm{T}-\mathrm{C}$ & $45.1 \mathrm{~b}$ & $41.6 \mathrm{c}$ & $3.5 \mathrm{a}$ & $10 \mathrm{a}$ & $75.2 \mathrm{~b}$ \\
\hline $\mathrm{T}-\mathrm{V}$ & $46.7 \mathrm{~b}$ & $43.6 \mathrm{bc}$ & $3.1 \mathrm{a}$ & $10 \mathrm{a}$ & $77.8 \mathrm{~b}$ \\
\hline T-VC & $48.8 \mathrm{~b}$ & $45.9 \mathrm{~b}$ & $2.9 \mathrm{a}$ & $9.8 \mathrm{a}$ & $81.3 \mathrm{~b}$ \\
\hline T-VK & $46.5 \mathrm{~b}$ & $43.3 \mathrm{bc}$ & $3.2 \mathrm{a}$ & $9.7 \mathrm{a}$ & $77.5 \mathrm{~b}$ \\
\hline T-VKN & $54.2 \mathrm{a}$ & $51.4 \mathrm{a}$ & $3.0 \mathrm{a}$ & $10.2 \mathrm{a}$ & $90.4 \mathrm{a}$ \\
\hline Average & 47.9 & 44.9 & 3.1 & 9.9 & 79.9 \\
\hline CV $(\%)^{*}$ & 6.0 & 6.13 & 21.6 & 2.8 & 7.3 \\
\hline
\end{tabular}

Means followed by letters distinct from each other in the column differ statistically from each other by the Tukey test at $5 \%$ level. *Coefficient of variation.

T-VKN treatment was superior to T-VK treatment, indicating that the addition of urea to this biofertilizer was the factor responsible for the increase in productivity. Similar results were observed for other banana cultivars by Senthilkumar et al. (2014) and El-Morshedy et al. (2020), when verifying increases in productivity ('Robusta' and 'Williams' cultivars, respectively), when adding nitrogen and potassium chemical fertilizers to biofertilizers compared to the conventional use of chemical fertilizers.

The use of urea in the biofertilizer solution alone cannot explain the productivity gain, since pure solution with urea was not tested. Thus, the effect of the T-VKN treatment is a combination of the biofertilizer constituent materials. The fact that productivity has increased due to the addition of urea to the biofertilizer solution is probably not justified only by the fact that nitrogen was metabolized and used for mass gain, as the necessary amount of nitrogen to positively respond to mass gain should be applied via roots in high amounts and not in green tissues (DEUNER et al., 2008; SOHRAB et al., 2017). 
Apparently, the positive effect of the addition of urea may be related to the ability of this substance to penetrate the cuticle and facilitate the entry of other substances, used as an adjuvant, by the facilitated diffusion and breaking of ester, ether and diether bonds of the cutin (CARVALHO et al., 2010), in order to allow the entry of other important elements for fruits, such as potassium and other nutrients present in the biofertilizer solution.

Deus et al. (2020) studied the partition of macronutrients in 'Prata' banana cultivar and found that potassium is the element required in greater amounts by the culture, especially in fruits, containing up to $21 \%$ of exported potassium in crop with high productivity. Based on the high demand of banana trees for potassium and the high penetration capacity of urea in green tissues, it could be inferred that the addition of urea to the biofertilizer allowed soluble potassium and other important elements, in addition to nitrogen, to enter and promote an increase in mass gain and consequently increase in productivity observed in this work.

It is noteworthy that some characteristics measured in this experiment, including productivity, are close to or above values reported in other studies with 'Terra Maranhão' banana cultivar (COELHO et al., 2013), demonstrating that the productivity of the commercial crop under study was well conducted and competitive among 'Terra Maranhão' banana producers.
Several studies report the use of biofertilizers or fertilizers in banana crops; however, none of them report direct application to fruits during bunch development (RIVERA-CRUZ et al., 2008; SILVA et al, 2011; GURAV; JADHAV, 2013; SANTOS et al., 2014; SENTHILKUMAR et al., 2014), even so, the application of commercial products aimed at banana bunches for productivity gains is currently a common practice among 'Terra Maranhão' banana producers in northern Espírito Santo, including the commercial production area where this experiment was carried out, but without any scientific parameter that correlates production gain with the application of these products.

Regarding rachis weight (Table 4), no significant difference was observed among treatments, demonstrating that weight gain was exclusive to bunches (Table 5), which culminated in productivity gain. It is important to highlight that the 'Terra Maranhão' banana cultivar is sold without rachis, only bunches, thus, the producer achieves greater productivity in the area and, consequently, greater profitability in the crop using biofertilizer applied directly to bunches, according to methodology applied in this experiment. Even though, the rachis of banana bunches is not a product targeted at commercial plantations, some authors have pointed out its potential for use in animal feed in the form of silage (CAICEDO et al., 2020).

Table 5. Effect of seven applications, during the production phase, with different products and mixtures of biofertilizer and chemical fertilizers in 'Terra Maranhão' banana bunches on variables Weight of the third bunch (PTP), Fruit weight (PF), Peel Weight (PC), Pulp Weight (PP) and Total Soluble Solids (SST) of fruits with full natural maturation.

\begin{tabular}{|c|c|c|c|c|c|}
\hline Treatment & $\begin{array}{l}\text { PTP } \\
\mathrm{Kg}\end{array}$ & $P F$ & $\begin{array}{c}\text { PC } \\
-\end{array}$ & PP & $\begin{array}{l}\text { SST } \\
{ }^{\circ} \text { Brix }\end{array}$ \\
\hline T-0 & $5.2 \mathrm{~b}$ & $236.6 \mathrm{a}$ & $47.2 \mathrm{a}$ & $189.3 \mathrm{ab}$ & $29.1 \mathrm{ab}$ \\
\hline $\mathrm{T}-\mathrm{C}$ & $5.0 \mathrm{~b}$ & $223.7 \mathrm{a}$ & $44.4 \mathrm{a}$ & $179.2 \mathrm{ab}$ & $28.3 \mathrm{abc}$ \\
\hline $\mathrm{T}-\mathrm{V}$ & $5.5 \mathrm{ab}$ & $224.5 \mathrm{a}$ & $43.9 \mathrm{a}$ & $180.6 \mathrm{ab}$ & $29.4 \mathrm{a}$ \\
\hline $\mathrm{T}-\mathrm{VC}$ & $5.0 \mathrm{~b}$ & $210.4 \mathrm{a}$ & $41.5 \mathrm{a}$ & $168.9 \mathrm{~b}$ & $28.8 \mathrm{abc}$ \\
\hline $\mathrm{T}-\mathrm{VK}$ & $5.3 \mathrm{~b}$ & $223.4 \mathrm{a}$ & $47.1 \mathrm{a}$ & $176.2 \mathrm{ab}$ & $27.8 \mathrm{bc}$ \\
\hline T-VKN & $6.2 \mathrm{a}$ & $250.5 \mathrm{a}$ & $44.6 \mathrm{a}$ & $205.8 \mathrm{a}$ & $27.8 \mathrm{c}$ \\
\hline Average & 5.4 & 228.2 & 44.8 & 183.3 & 28.5 \\
\hline $\mathrm{CV}(\%)^{*}$ & 8.0 & 12.4 & 13.7 & 13.8 & 3.2 \\
\hline
\end{tabular}

Means followed by letters distinct from each other in the column differ statistically from each other by the Tukey test at $5 \%$ level. *Coefficient of variation.

By analyzing fruits, it was possible to observe that pulp weight was positively affected by the application of the T-VKN treatment; however, regarding the TSS content of fruits, this treatment provided significant drop in relation to the other treatments. Other characteristics such as peel weight and fruit weight (finger) were not affected by treatments. This information implies that the weight gain that culminated in increased productivity with the application of biofertilizer occurred in the edible part of fruits (pulp) and not in the banana peel.
Freitas et al. (2019) reported that the increase in nitrogen doses in experiment carried out with 'Prata-anã' banana cultivar favored the increase in fruit and pulp weight and increased the TSS content; however, Nomura et al. (2020), studying three 'Prata' banana varieties, did not observe effects resulting from nitrogen or even potassium fertilization on postharvest characteristics, including TSS content and reported that the postharvest characteristics of bananas are very intrinsic to their genetic characteristics and little influenced by fertilization. Both experiments by Freitas et al. (2019) and Nomura et al. (2020) received soil 
fertilization, differing from the experiment carried out in this study, which used, in addition to the recommended soil fertilization, additional fertilization with biofertilizers directed to 'Terra Maranhão' banana bunches.

Based on the information previously discussed, the fact that T-VKN treatment has urea as the main difference from the other treatments, leads us to reflect on the importance of this fertilizer in the biofertilizer solution, which provided mass gain in fruits of this experiment, despite the drop in SST content. The higher average bunch weight and pulp weight, culminating in increased productivity, causes an expected postharvest effect in relation to the SST content, that is, there is negative correlation already reported in literature between increase in fruit mass and SST content, possibly related to the dilution effect of SST with increase in fruit volume and mass (AMARO et al., 2017).

There are still relevant questions arising from this research such as whether the changes in ripe fruits caused by treatment that increased productivity by $17 \%$ (T-VKN) are reflected in the sensory consumption characteristics of 'Terra Maranhão' banana cultivar, and therefore future studies should be carried out to obtain these answers.

\section{Conclusion}

The use of biofertilizer based on cachaça vinasse associated with conventional chemical fertilizers, such as urea and potassium chloride, did not affect the postharvest morphological characteristics of 'Terra Maranhão' banana bunches and fruits; however, it provided increase in productivity by $17 \%$ and decrease in SST content of 1.3 ${ }^{\circ}$ Brix in relation to control.

\section{Acknowledgments}

The authors would like to thank the financial support given by the Federal Institute of Espírito Santo (IFES); the Espírito Santo Research and Innovation Support Foundation (FAPES) and the National Council for Scientific and Technological Development (CNPq).

\section{References}

ALVES, E.J. A cultura da banana: aspectos técnicos, socioeconômicos e agroindustriais. 2.ed. Cruz das Almas: Embrapa, 1999. 585 p.

AMARO, G.B., SILVA, G.O.; BOITEUX, L.S.; CARVALHO, A.D.; LOPES, J.F. Desempenho agronômico de híbridos experimentais de abóbora Tetsukabuto para características dos frutos. Horticultura Brasileira, Brasília, DF, v.35, n.2, p.180-185, 2017.

BERILLI, S.S.; DE SALES, R.A.; RIBEIRO, H.R.; ZOOCA, A.A.F.; DE SALLES, R.A.; BERILLI, A.P.C.G.; RIBEIRO W.R.R.; FREITAS, S.J.; COSTA, T.S. Foliar fertilization in the propagation of conilon coffee in alternative substrates. International Journal of Agriculture and Natural Resources, Santiago, v.47, n. 1, p.58-68, 2020.

CAICEDO, W.; VIÁFARA, D.; PÉREZ, M.; FERREIRA, F.N.A.; RUBIO, G.; YANZA, R.; CAICEDO, M.; CAICEDO, L.; VALLE, S.; FERREIRA, W. M. Características químicas del ensilado de raquis de plátano (Musa paradisiaca) y banano orito (Musa acuminata AA) tratado con suero de leche y urea. Revista de Investigaciones Veterinarias del Perú, Lima, v.31, n.4, p.19035-19035, 2020.

COELHO, E.F.; OLIVEIRA, R.C.D.; PAMPONET, A.J.M. Necessidades hídricas de bananeira tipo Terra em condições de tabuleiros costeiros. Pesquisa Agropecuária Brasileira, Brasília, DF, v.48, n.9, p.1260-1268, 2013.

COSTA, M.S.; ROLIM, M.M.; DA SILVA, G.F.; NETO, D.E.S.; PEDROSA, E.M.R. Nutrient content and accumulation in sugarcane under mineral fertilization and high doses of vinasse. Semina, Londrina, v.42, n.2, p.565-582, 2021.

DAVARPANAH, S.;TEHRANIFAR,A.;DAVARYNEJAD, G.; ARAN, M.; ABADÍA, J.; KHORASSANI, R. Effects of foliar nano-nitrogen and urea fertilizers on the physical and chemical properties of Pomegranate (Punica granatum cv.Ardestani) fruits. HortScience, Alexandria, v.52, n.2, p.288-294, 2017. 
DEUNER, S.; NASCIMENTO, R.D.; FERREIRA, L.S.; BADINELLI, P.G.; KERBER, R.S. Adubação foliar e via solo de nitrogênio em plantas de milho em fase inicial de desenvolvimento. Ciência e Agrotecnologia, Lavras, v.32, n.5, p.1359-1365, 2008.

DEUS, J.A.L.D.; NEVES, J.C.L.; LIMA NETO, A.J.D.; NATALE, W.; ALVAREZ V.V.H.; ALBUQUERQUE, F.M.R.D. Partitioning of macronutrients and nutritional efficiency in fertigated prata banana. Revista Brasileira de Fruticultura, Jaboticabal, v.42, n.4, p.e-611, 2020.

EL-MORSHEDY, F.; AYAAD, H.; ABOU ELYAZID, D.M.; OMER, M.K. Enhancing banana (Musa spp.) Growth and productivity by bio-fertilizers in sandy soil. Applied Ecology and Environmental Research, Indialantic, v.18, n.5, p.6765-6773, 2020.

FERREIRA, C.F. ; SANTOS-SEREJO, J. BRS PL01: Plátano Terra Maranhão de porte alto e elevada produtividade. Brasília (DF): Registro Nacional de Cultivares, 2018. (Número do Registro: 38402).

FREITAS, V.A.; FERNANDES, M.B.; MIZOBUTSI, E.H.; MIZOBUTSI, G.P.; RIBEIRO, R.C.F.; PEGORARO, R.F. Anthracnose intensity and physical and chemical characteristics of 'Prata anã'banana under different nitrogen doses. Revista Brasileira de Fruticultura, Jaboticabal, v.41, n.5, p.e-050, 2019.

FU, L.; PENTON, C.R.; RUAN, Y.; SHEN, Z.; XUE, C.; LI, R.; SHEN, Q. Inducing the rhizosphere microbiome by biofertilizer application to suppress banana Fusarium wilt disease. Soil Biology and Biochemistry, Oxford, v.104, p.39-48, 2017.

GURAV, R.G.; JADHAV, J.P.A novel source of biofertilizer from feather biomass for banana cultivation. Environmental Science and Pollution Research, Bordeaux, v.20, n.7, p.4532-4539, 2013.

HUANG, J.; PANG, Y.; ZHANG, F.; HUANG, Q.; ZHANG, M.; TANG, S.; FU, H.; LI, P. Suppression of Fusarium wilt of banana by combining acid soil ameliorant with biofertilizer made from Bacillus velezensis H-6. European Journal of Plant Pathology, London, v.154, n.3, p.585-596, 2019.
NOMURA, E.S.; CUQUEL, F.L.; DAMATTO JUNIOR, E.R.; BEZERRA, D.P.; BORGES, A.L. Post-harvest characterization of 'Prata' banana cultivar grown under different nitrogen and potassium fertilization. Revista Brasileira de Fruticultura, Jaboticabal, v.41, n.4, p.e416, 2019.

REIS, R.C.; VIANA, E.S; ASSIS, S.; LIMA F.S.; LUISE O.; SOUZA, A.S.; AMORIM, E.P. Promising green banana and plantain genotypes for making flour. Pesquisa Agropecuária Brasileira, Brasília, DF, v.54, n.2, p.e01303, 2019.

RIVERA-CRUZ, M.C.; NARCÍA, A.T.; BALLONA, G.C.; KOHLER, J.; CARAVACA, F.; ROLDAN, A. Poultry manure and banana waste are effective biofertilizer carriers for promoting plant growth and soil sustainability in banana crops. Soil Biology and Biochemistry, Oxford, v.40, n.12, p.3092-3095, 2008.

SANTOS, J.G.; ANDRADE, R.; GALDINO, P.O.; LINHARES, A.S.; MAIA, P.M.; LIMA, A.S.D. Qualidade da produção da bananeira Nanicão em função do uso de biofertilizantes. Revista Brasileira de Engenharia Agrícola e Ambiental, Jaboticabal, v.18, n.4, p.387-393, 2014.

SENTHILKUMAR, M.; GANESH, S.; SRINIVAS, K.; PANNEERSELVAM, P. Influence of fertigation and consortium of bio fertilizer on photosynthesis, chlorophyll content, yield parameters and yield of banana cv.Robusta (AAA). Plant Archives, Etawah, v.14, n.1, p.387-391, 2014.

SILVA, J.T.A.D.; PEREIRA, R.D.; SILVA, I.P.; OLIVEIRA, P.M.D. Produção da bananeira 'Prata anã' (AAB) em função de diferentes doses e fontes de potássio. Revista Ceres, Viçosa, MG, v.58, n.6, p.817-822, 2011.

WIDYANTORO, A.; HADIWIYONO, S. Biological control of Fusarium wilt on banana plants using biofertilizers. Biodiversitas Journal of Biological Diversity, Surakarta, v.21, n.5, p.2119-2123, 2020. 